\title{
Isolated oculomotor nerve palsy due to common carotid artery occlusion
}

\author{
B K Man, Y P FU
}

Department of Medicine and Geriatrics, Tuen Mun Hospital, Hong Kong

Correspondence to Dr B K Man,

beli_man@yahoo.com
To cite: Man BK, FU YP. BMJ Case Rep Published online: [please include Day Month Year] doi:10.1136/ bcr-2013-201338

\section{DESCRIPTION}

Oculomotor nerve palsy as the only manifestation of ipsilateral common carotid artery occlusion is rare. ${ }^{1-3}$ A 31-year-old man had history of nasopharyngeal carcinoma with radiation therapy performed when he was at the age of 14 . He developed diplopia during work. He denied any weakness, headache or change in mental status. His blood pressure was normal on admission. The physical examination found right partial ptosis with limitation in elevation, adduction and depression. The right pupil was dilated and non-reactive (figure 1). Other cranial nerves were normal. The limb power was full. The blood tests showed a normal full blood count and clotting profile. Brain MRI showed thrombosis and occlusion of right internal carotid artery (ICA) (figure 2) and no cerebral infarct was seen. A standard cerebral catheter angiogram showed complete obliteration of right common carotid artery at its origin with a residual stump (figure 2) and no arterial dissection was found.

The oculomotor nerve is fed by small arteries arising from the basilar artery, posterior communicating artery, thalamoperforating arteries from the posterior cerebral artery, the cavernous portion of the ICA and the ophthalmic artery. ${ }^{4}$ The oculomotor nerve palsy in our patient was likely caused by ischaemia due to impairment of blood supply from the cavernous portion of the ICA. The lack of other neurological deficits could be related to adequacy of the collateral blood supply. Patients who received neck irradiation for nasopharyngeal carcinoma are at risk for the delayed development of diffused atherosclerosis and carotid occlusion, the mechanism remains elusive and probably multifactorial..$^{5}$

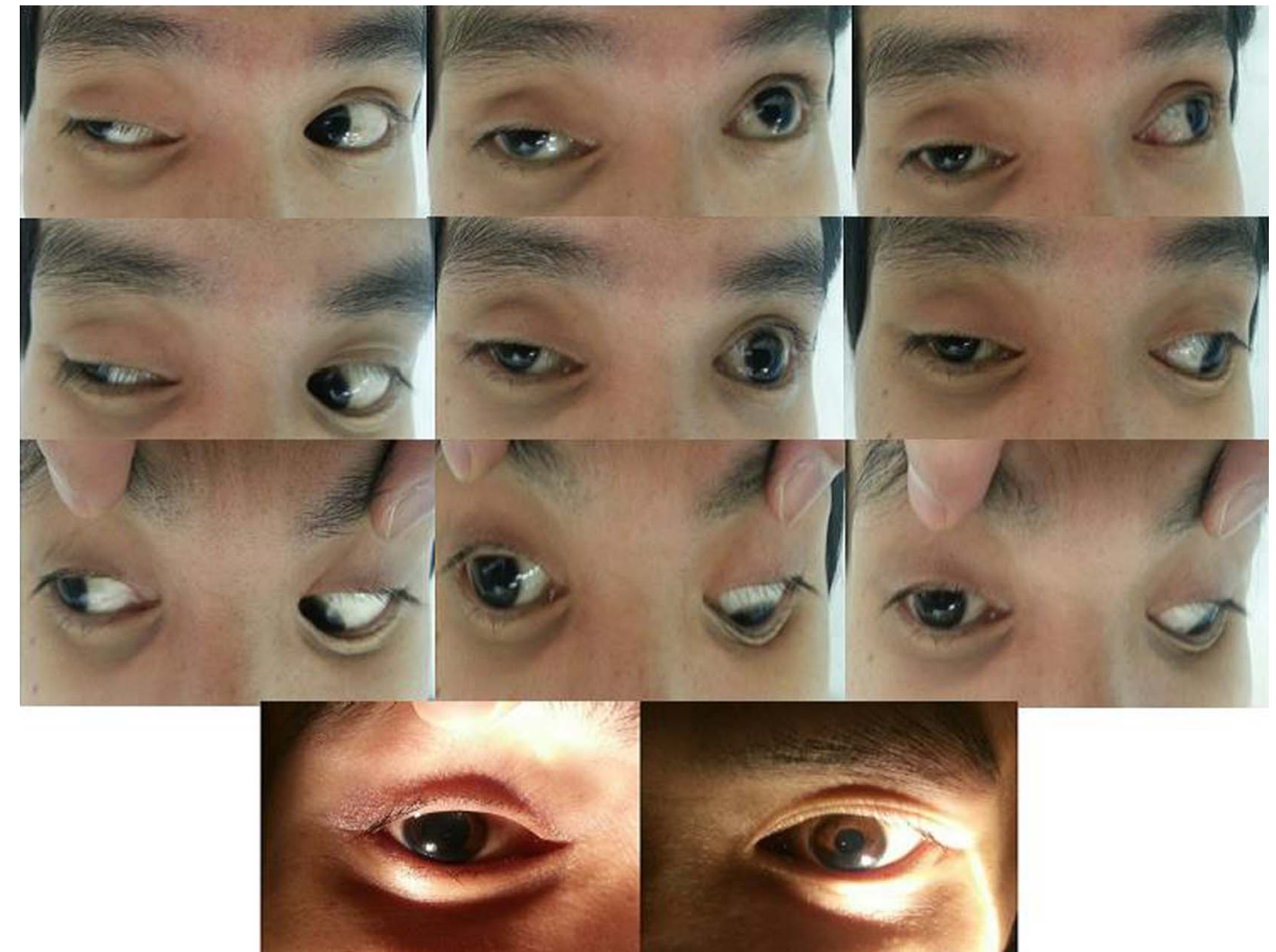

Figure 1 Right oculomotor nerve palsy. Physical examination found right partial ptosis with limitation in elevation, adduction and depression. The right pupil was dilated and non-reactive. 

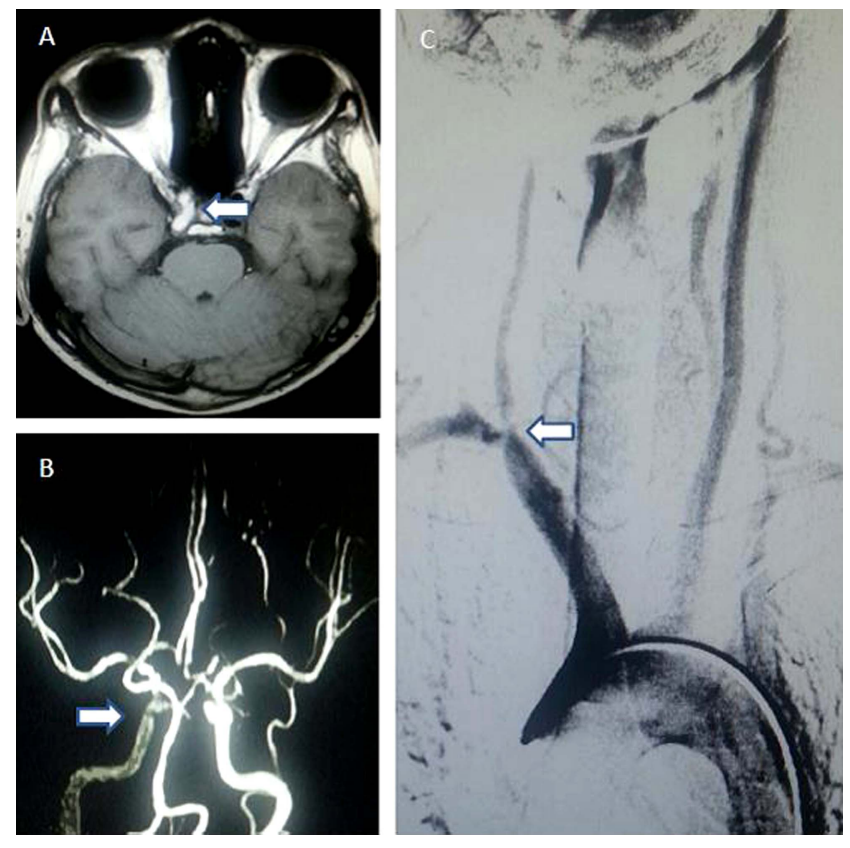

Figure 2 MRI of the brain and cerebral angiogram. (A) T1Weighted MRI of the brain showed entire intracranial portion of right internal carotid artery (ICA) was hyperintense, indicating marked slow flow and thrombosis (arrow). (B) MR angiogram showed near total occlusion of right ICA (arrow). (C) Cerebral catheter angiogram showed complete obliteration of right common carotid artery at its origin with a residual stump (arrow).

\section{Learning points}

- Isolated oculomotor nerve palsy can be the only manifestation of common carotid artery occlusion.

- Patients who received neck irradiation for nasopharyngeal carcinoma are at risk for the delayed development of diffused atherosclerosis and carotid occlusion.

Competing interests None.

Patient consent Obtained.

Provenance and peer review Not commissioned; externally peer reviewed.

\section{REFERENCES}

1 Balcer LJ, Galetta SL, Yousem DM, et al. Pupil-involving third-nerve palsy and carotid stenosis: rapid recovery following endarterectomy. Ann Neurol 1997;41:273-6.

2 Thomke F, Ringel K, Schindler $\mathrm{H}$, et al. Pupil-sparing oculomotor palsy as the only clinical sign of an internal carotid artery occlusion. Eur J Neurol 1999;6:378.

3 Watanabe A, Horikoshi T, Uchida M, et al. Internal carotid artery occlusion manifesting only as oculomotor nerve palsy. I Stroke Cerebrovasc Dis 2008;17:433-5.

4 Lapresle J, Lasjaunias P. [Cranial nerve vascular syndromes caused by ischemia, cerebral trunk excepted]. Bull Acad Natl Med 1986;170:797-802.

5 Li CS, Schminke U, Tan TY. Extracranial carotid artery disease in nasopharyngeal carcinoma patients with post-irradiation ischemic stroke. Clin Neurol Neurosurg 2010;112:682-6.

Copyright 2013 BMJ Publishing Group. All rights reserved. For permission to reuse any of this content visit http://group.bmj.com/group/rights-licensing/permissions.

BMJ Case Report Fellows may re-use this article for personal use and teaching without any further permission.

Become a Fellow of BMJ Case Reports today and you can:

- Submit as many cases as you like

- Enjoy fast sympathetic peer review and rapid publication of accepted articles

- Access all the published articles

- Re-use any of the published material for personal use and teaching without further permission

For information on Institutional Fellowships contact consortiasales@bmjgroup.com

Visit casereports.bmj.com for more articles like this and to become a Fellow 